\title{
Response of a microbial food web to prolonged seasonal hypoxia in a boreal lake
}

\author{
Grażyna Bręk-Laitinen*, Jessica López Bellido, Anne Ojala \\ Department of Environmental Sciences, University of Helsinki, 15140 Lahti, Finland
}

\begin{abstract}
The clearwater boreal Lake Vesijärvi experiences annual periods of hypolimnetic hypoxia with unknown consequences for the microbial food web. We quantified the abundance of heterotrophic bacteria, autotrophic picoplankton (APP), nanoflagellates (NF) and ciliates in Lake Vesijärvi throughout the water column and vegetation season and determined how these varied with changes in environmental conditions, including dissolved oxygen concentrations. The abundance and diversity of ciliates increased significantly throughout the water column with the development of thermal stratification and the onset of hypoxia leading to distinct ciliate communities in the oxic epilimnion and hypoxic hypolimnion. Bacterivorous taxa dominated in the hypoxic zone, while in the epilimnion, bacterivorous, algivorous and predatory taxa feeding on other protozoa were present. Seasonal changes in oxygen and temperature explained nearly $80 \%$ of variance in ciliate community composition. Changes in total ciliate numbers correlated with seasonal dynamics of bacteria, but not with the dynamics of NF. In the epilimnion, NF were abundant in early spring and their numbers were positively correlated to numbers of prostomatids and haptorids, but not to APP or bacteria. In the hypolimnion, a significant correlation was found between NF and bacteria, but not NF and ciliates. Significant positive correlations between ciliates and bacteria suggest that concentrations of food resources are important in determining the abundance of ciliates in the plankton. Moreover, we recorded close coupling between seasonal dynamics of bacteria and productivity of phytoplankton, including APP.
\end{abstract}

KEY WORDS: Autotrophic picoplankton · Bacteria · Nanoflagellates $\cdot$ Ciliates $\cdot$ Anoxia $\cdot$ Hypoxia

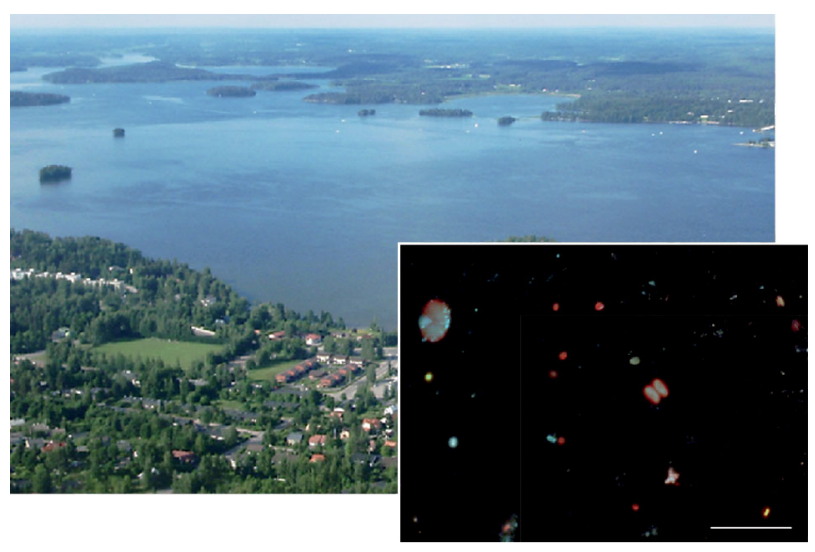

Hypoxia strongly influences the microbial community of Lake Vesijärvi, Finland. Inset: epifluorescence micrograph of APP cells (red), and DAPI signals of DNA containing cells (blue); scale bar $=10 \mu \mathrm{m}$.

Photos: G. Bręk-Laitinen

\section{INTRODUCTION}

Low oxygen content in the hypolimnion has become a widespread phenomenon in lacustrine as well as marine ecosystems worldwide (Diaz 2001). Hypoxia, defined as dissolved oxygen concentrations $<2 \mathrm{mg} \mathrm{l}^{-1}$, typically arises from water column stratification, biological processes and nutrient inputs (Rabalais et al. 2007). While $<4 \mathrm{mg} \mathrm{O}_{2} \mathrm{l}^{-1}$ is considered stressful for fish, concentrations $<2 \mathrm{mg} \mathrm{O}_{2} \mathrm{l}^{-1}$ are stressful for most organisms. Specifically, low oxygen concentration is a stressor of benthic communities and can cause major alterations in energy flow (Diaz \& Rosenberg 2008). However, although the effects of hypoxia and anoxia on the benthos are quite well 
known, the consequences for microorganisms and ecosystem functioning further up in the water column are poorly defined (Eby et al. 2005).

Total anoxia also initiates major changes in the biogeochemistry of lakes (Finlay et al. 1997). Some energy is processed by benthic animals under persistent hypoxia and anoxia, but organic matter is mostly processed through microbes (Diaz \& Rosenberg 2008). A series of electron acceptors other than oxygen are used by functional microbial groups, i.e. nitrate reduction is followed by reduction of manganese, iron and sulphate, and finally methanogenesis takes over, resulting in fluxes of methane (Finlay et al. 1997). Methanogenic Archaea become dominant decomposers in anoxic freshwaters with elevated hypolimnetic temperatures (Glissmann et al. 2004). Enhanced epilimnetic primary production, a result of internal loading through the release of phosphorous contained in lake sediment, leads to an accumulation of particulate organic matter, which further encourages microbial activity. In low oxygen conditions, zooplankton grazing is suspended and protozoa such as nanoflagellates (NF) and ciliates appear as the main grazers (Marcus 2001).

NF and ciliates are key components of the so-called microbial loop, which is a crucial part of pelagic food webs (Azam et al. 1983). Autotrophic picoplankton (APP; size <2.0 $\mu \mathrm{m}$ ) is an important source of organic carbon for other microorganisms, hence the concept of a microbial food web instead of a microbial loop (Sherr \& Sherr 2000). NF, which have high growth efficiencies, may effectively control communities of APP in the euphotic zone as well as heterotrophic picoplankton (i.e. bacteria) and their abundance is usually 1 to 2 orders of magnitude higher than that of ciliates (Šimek et al. 1997). NF reside in the water column throughout the oxygen gradient (Gobler et al. 2008) and their grazing efficiency is more affected by temperature than by decreases in oxygen concentrations (Park \& Cho 2002). Ciliates are more sensitive to changes in oxygen and show dramatic responses in community composition (Finlay \& Esteban 1998), with their abundance and growth rates often declining in the hypoxic zone (Guhl et al. 1994). The oxygen gradient separates ciliate taxonomic composition and creates a characteristic spatial organisation with vertical distribution patterns. Epilimnetic aerobic ciliates do not cross the oxycline, while microaerophiles, due to a narrow preference range for oxygen pressure, are found mainly around the oxycline, where they form clear bands (Fenchel \& Finlay 2008). Anaerobic ciliates are intolerant to oxygen and stay in the hypolimnion, below the oxycline. Some ciliates respond to oxygen in accordance with the needs of their endo- or ectosymbiotic organisms. Many aerobic ciliates harbour oxygenic algal symbionts, which allow them to thrive even in very low oxygen concentrations (Finlay \& Esteban 1998). While ciliate communities in the epilimnion display various feeding modes attributed to the vast array of food choices, in the hypoxic zone, herbivory is disrupted and bacterivory dominates (Gobler et al. 2008).

Here we present the distribution patterns and seasonal trends of key components of the microbial food web in relation to hypoxia and anoxia in a mesoeutrophic, anthropogenically affected clearwater lake in southern Finland. Due to the lake morphometry and eutrophication, the hypolimnion in one of the major basins regularly experiences an extended, persistent period of hypoxia in summer, when the lake is stratified (Kairesalo \& Vakkilainen 2004). The implications of this phenomenon are numerous, including an impact on fishery yields and recruitment. Previous investigations of the lake have focused on the chemical and physical environment, larger phytoplankton, zooplankton and fish stocks in relation to biomanipulation (Horppila et al. 1996). To date no studies have been conducted on the microbial and protozoan community in this lake and, in general, the knowledge of microbial food webs in non-humic boreal lakes is fragmentary. We particularly intended to gain insight into the dynamic nature of the ciliate community in relation to the development of seasonal hypoxia. We expected to find clear spatial patterns in community composition, which in turn affect abundance of other components of the microbial food web, namely APP, bacteria and NF. Based on previous grazing experiments (Bręk-Laitinen \& Ojala 2011), we hypothesised that, among microconsumers, NF are significantly coupled with picoplankton throughout the water column and growing season, whereas the ciliate community with dynamic vertical patterns imposes a temporary pressure only on certain components of the microbial food web. As the development of hypoxia may decrease the number of habitat niches and food diversity in anoxic parts of the water column (Guhl et al. 1994), we also expected to find a lower diversity of ciliated protozoa during thermal stratification.

\section{MATERIALS AND METHODS}

\section{Study site}

Lake Vesijärvi is a large glacial drift lake in the Kymijoki River basin in southern Finland, with a 
length of $25 \mathrm{~km}$, a total area of $111 \mathrm{~km}^{2}$ and a catchment to lake-surface ratio of approximately 4.6. In contrast to most lakes in Finland, which have brown water, Lake Vesijärvi is a clearwater lake with a colour value of $30 \mathrm{mg} \mathrm{Pt} \mathrm{l}^{-1}$ (Kansanen et al. 1991). The epilimnetic dissolved organic (DOC) and inorganic (DIC) carbon concentrations during the growing season both average $7.3 \mathrm{mg} \mathrm{C} \mathrm{l}^{-1}$, without seasonal patterns or depth profiles. The low colour value in contrast to high DOC concentration indicates that autochthonous colourless DOC is abundant in Lake Vesijärvi. The lake has mean and maximum depths of $6 \mathrm{~m}$ and $42 \mathrm{~m}$, respectively, and its theoretical residence time is ca. $9 \mathrm{yr}$ (K. Vakkilainen pers. comm.). The lake, which is ice-covered from November or December until April or May, is divided into 4 main basins. The city of Lahti with its 100000 inhabitants is situated at the southern end of the lake, near the Enonselkä basin (mean depth: $6.8 \mathrm{~m}$, maximum depth: $33 \mathrm{~m}$, surface area: $26 \mathrm{~km}^{2}$ ). Permanent dwellings and industry cover $98 \%$ of the basin's drainage area (S. Kajander pers. comm.). We carried out our study in the Enonselkä basin, which since the 1960s has suffered from severe anthropogenic eutrophication (Kairesalo \& Vakkilainen 2004). The lake has been restored through biomanipulation involving large-scale removal of fish since 1989, and it is currently regarded as a mesoeutrophic lake.

\section{Sampling and measurements}

Samples were collected once per week between 09:00 and 11:00 h from 18 May to 18 October 2005 at the deepest point of the Enonselkä basin $\left(61^{\circ} 01^{\prime} \mathrm{N}\right.$, $25^{\circ} 36^{\prime} \mathrm{E}$ ), except for during periods of high winds that excluded the possibility of field activities. Temperature $\left({ }^{\circ} \mathrm{C}\right)$ and oxygen $\left(\mathrm{mg} \mathrm{l}^{-1}\right)$ were profiled for each sampling date with a temperature-compensated dissolved oxygen meter (YSI 52, Yellow Springs Instruments). The readings were taken at $1 \mathrm{~m}$ intervals through the water column from the surface to $10 \mathrm{~m}$ depth and then every $2.5 \mathrm{~m}$ to the bottom.

Water samples were collected with a $1 \mathrm{~m}$ long acrylic tube sampler (Limnos; volume $7 \mathrm{l}$ ) at $1 \mathrm{~m}$ intervals and then pooled into depth classes of $0-5$, 5-10, 10-15, 15-20, 20-25 and 25-28 m. Subsamples for enumerating bacteria, NF, microzooplankton (ciliates), $\mathrm{pH}$ and chlorophyll a ( $\mathrm{chl}$ a) concentration were drawn from the $35 \mathrm{l}$ pooled samples. To collect samples for water chemistry (total phosphorus [TP] and nitrogen [TN]), the $0-5$ and $25-28 \mathrm{~m}$ depth classes were used. Bacteria, NF and ciliate samples were transferred to $150 \mathrm{ml}$ dark glass bottles and fixed immediately with acid Lugol's iodine solution to a final concentration of $1 \%$ (Throndsen 1978). Samples for APP were taken with the same tube sampler, starting from the surface down to a depth of $15 \mathrm{~m}$ at $1 \mathrm{~m}$ intervals and collected with the same type of bottles as described in the previous sentence. Unpreserved APP samples were placed in crushed ice and counted within $2 \mathrm{~h}$. Before summer stratification, the APP samples were taken only from a depth of 0 to $6 \mathrm{~m}$, which was assumed to represent the cell densities throughout the mixed water column. Sampling of depths up to $15 \mathrm{~m}$ continued after the thermocline had formed.

The total nutrients (TP and TN) were determined from unfiltered samples stored at $-18^{\circ} \mathrm{C}$. The nutrients were determined photometrically with a flow injection analyser (QuikChem ${ }^{\circledR 8000}$, Zellweger Analytics, Lachat Instruments Division) using the manufacturer's instructions.

Water for chl a determination was collected in darkened plastic bottles, and a subsample of 100 to $1000 \mathrm{ml}$ was filtered onto a Whatman GF/C filter. Filters were frozen and stored at $-18^{\circ} \mathrm{C}$. The chlorophyll was hot-extracted in $10 \mathrm{ml}$ of $94 \%$ ethanol at $75^{\circ} \mathrm{C}$ for 5 min and analysed with a Shimadzu UV 2100 spectrophotometer at a wavelength of $675 \mathrm{~nm}$. Chl a concentration was calculated using an absorption coefficient of $83.4 \mathrm{l} \mathrm{g}^{-1} \mathrm{~cm}^{-1}$ (Wintermans \& DeMots 1965).

Primary production (PP) was measured with the ${ }^{14} \mathrm{C}$ technique (Steemann-Nielsen 1952). Samples were taken from depths of $0,1,2,4$ and $6 \mathrm{~m}$ and incubated with $10 \mu \mathrm{l}$ of $\mathrm{NaH}^{14} \mathrm{CO}_{3}$ solution (specific activity: 6.72 $\mathrm{MBq} \mathrm{mmol}^{-1}$; Sonar) for $24 \mathrm{~h}$ in situ at the initial depths. Samples were processed and measured as explained in Peltomaa \& Ojala (2010).

Samples for the measurement of bacterial production (BP) were taken from the same depths as for PP. The BP was measured in situ for $1 \mathrm{~h}$, with samples incubated with $100 \mu \mathrm{l}$ of ${ }^{14} \mathrm{C}$-leucine (specific activity: 11.3 GBq mmol ${ }^{-1}$; Amersham Biosciences) (Simon \& Azam 1989). Formaldehyde-killed controls were run in parallel. Measurements of radioactivity were carried out in the laboratory immediately after incubation as described in Kankaala et al. (2006). The leucine incorporation rates were converted to carbon production using a factor of $7.71 \times 10^{15} \mu^{3} \mathrm{~mol}^{-1}$ and a biomass-to-carbon conversion factor of $0.36 \mathrm{pg} \mathrm{C}$ $\mu^{-3}$ (Tulonen 1993). In time series we used mean values of $\mathrm{BP}$ and $\mathrm{PP}$ over the depth of 0 to $6 \mathrm{~m}$.

APP samples were counted using the autofluorescence of chl a (Davis \& Sieburth 1982). Unpreserved samples (1 to $5 \mathrm{ml}$ ) were filtered onto black polycar- 
bonate membrane filters (pore size: $0.2 \mu \mathrm{m}, \varnothing 25 \mathrm{~mm}$; Osmonics) using a vacuum pump (pressure $<20 \mathrm{~mm}$ $\mathrm{Hg}$ ) and examined with a Nikon Eclipse E600 epifluorescence microscope under $1000 \times$ total magnification. Either 50 fields of view or up to 400 cells, whichever target was reached first, were counted to obtain an accuracy of $10 \%$. Standard filter blocks for green light (filter block G-2A; EX 510-560, DM 565, BA 590) and blue light (filter block B-2A; EX 450-490, DM 500, BA 515) excitation were used to differentiate phycocyanin (PC)-rich and phycoerythrin (PE)-rich cells (Callieri 2008). These 2 types were distinguished and counted separately from July to September, when APP was most abundant. We occasionally encountered aggregates at times of highest APP densities, which were also included in cell counts. APP cells were considered as spheres, and the diameter of approximately 100 APP cells per sample was calculated using an ocular grid. The mean cell diameter $r(0.6 \mu \mathrm{m})$ and cell density $n\left(\right.$ cells $\left.\mathrm{ml}^{-1}\right)$ were used to estimate the biovolume $B_{v}\left(\mu \mathrm{m}^{3}\right)$ of the APP according to the equation:

$$
B_{V}=n \times \frac{4}{3} \pi r^{3}
$$

$B_{V}$ was converted to chl a concentration using a factor

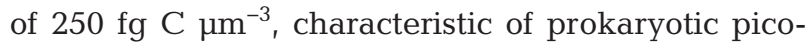
plankton, and a carbon-to-chlorophyll ratio of 22.5 (Søndergaard 1991). We used a constant cellular chl a content for APP to calculate the contribution of APP to total phytoplankton (G. Bręk-Laitinen unpubl. data). In the time series we used the mean APP numbers between the depths 0 and $6 \mathrm{~m}$, while counts obtained from 10 and $15 \mathrm{~m}$ were treated as representative of the depths of 5-10 and 10-15 m, respectively.

Lugol-preserved samples for bacteria and NF counts were decolourised with drops of saturated solution of $\mathrm{Na}_{2} \mathrm{~S}_{2} \mathrm{O}_{3}$ (Throndsen 1978) and filtered onto black polycarbonate membrane filters $(\varnothing 25 \mathrm{~mm}$; Osmonics) using a vacuum pump (pressure $<20 \mathrm{~mm}$ $\mathrm{Hg}$ ). Filters were stained for $15 \mathrm{~min}$ with acriflavine (Bergström et al. 1986), after which the orangefluorescing cells were counted under blue light and 1000x magnification using epifluorescence microscopy (Nikon Eclipse E600, filter block B-2A). To differentiate the autofluorescence of phytoplankton in samples stained with acriflavine, in addition to the blue light, we used UV light (Raghukumar \& Schaumann 1993). For bacterial counts, $1 \mathrm{ml}$ of sample was filtered onto a $0.2 \mu \mathrm{m}$ pore size filter, whereas the sample volume was $20 \mathrm{ml}$ and pore size $0.8 \mu \mathrm{m}$ for NF counts. The cells were counted from 50 random fields of view per sample. The pigmented flagellates are usually considered to be autotrophs and non-pigmented flagellates to be bacterivores, but we did not differentiate between flagellates with and without chloroplasts since pigmented flagellates can also be mixotrophic (Sanders et al. 1989). Samples for bacteria and NF taken in October were damaged beyond recognition, and thus, were excluded.

The ciliate community composition was determined using the Utermöhl technique (Utermöhl 1958). Volumes of $50 \mathrm{ml}$ were allowed to settle for at least $24 \mathrm{~h}$, and the entire content of each counting chamber was surveyed. The ciliates were identified and enumerated with an inverted microscope (Olympus IX50 or Nikon diaphot-TMD) at 200 to $1000 \times$ magnification. They were identified to genus level (Foissner \& Berger 1996) where possible and the taxonomy followed Lynn (2008). Changes in biodiversity at the genus level were studied using the Shannon-Wiener diversity index (Krebs 1999). In addition to taxonomy, ciliates were divided into bacterivores and herbivores on the basis of Foissner et al. (1999). To divide the ciliates into different feeding types, we used published data from grazing studies (e.g. Anderson 1987) and classified the ciliates into those feeding preferably on particles of $<2 \mu \mathrm{m}$ (picophagous), 2 to $20 \mu \mathrm{m}$ (nanophagous) or $>20 \mu \mathrm{m}$ in size (microphagous), and finally to carnivorous. The first 20 specimens encountered for each taxon were measured where possible. Sizing of the particles was done under the microscope with a calibrated eye-piece ocular micrometer under $400 \times$ magnification. The diameter or greatest length, if not spherical, of the ciliate individual was measured. Rimostrombidium spp. was subdivided into 3 size classes according to the largest linear dimension: <35, 35-50 and >50 $\mu \mathrm{m}$ (Müller et al. 1991).

\section{Statistical analyses}

We used the software package SPSS 15.0 for Windows for bivariate correlation and analysis of variance. For variables that did not follow a normal distribution (Kolmogorov-Smirnov test), we applied log transformation to meet the requirements for parametric statistics. For the pooled and depth-divided data set from the lake, we used bivariate correlation analysis (Pearson) to describe relationships between the measured biotic and abiotic variables. We also used multiple linear regression models to explore the variables best predicting the abundance of different groups of organisms. The level of significance was set at $p \leq 0.05$. Statistically significant differences in environmental variables between the depths were 
tested by 1-way ANOVA followed by the Bonferroni correction for multiple post hoc comparisons.

On the abundance data we applied canonical correspondence analysis (CCA) to display the variation in ciliate community composition and to link it to the measured environmental variables. The analyses were performed with PAST v.2.06. Environmental variables which contributed to the model significantly $(p<0.05)$ were included in the analysis using the manual selection of variables. Some autumn samples were removed from the CCA, because of missing values for bacteria and NF. Variables used in the analysis were abundance of APP, bacteria and NF, $\mathrm{PP}$, concentrations of chl $a$ and oxygen, water temperature; and $\mathrm{pH}$.

\section{RESULTS}

\section{Physical and chemical environment}

The lake was undergoing spring turnover at the onset of sampling, and it was not until mid-June that it began to stratify thermally. The period of stratification lasted until late August (Fig. 1A). The thermocline was between 6 and $10 \mathrm{~m}$ during stratification, and the epilimnetic and hypolimnetic water temperatures were on average 20 and $12^{\circ} \mathrm{C}$, respectively.
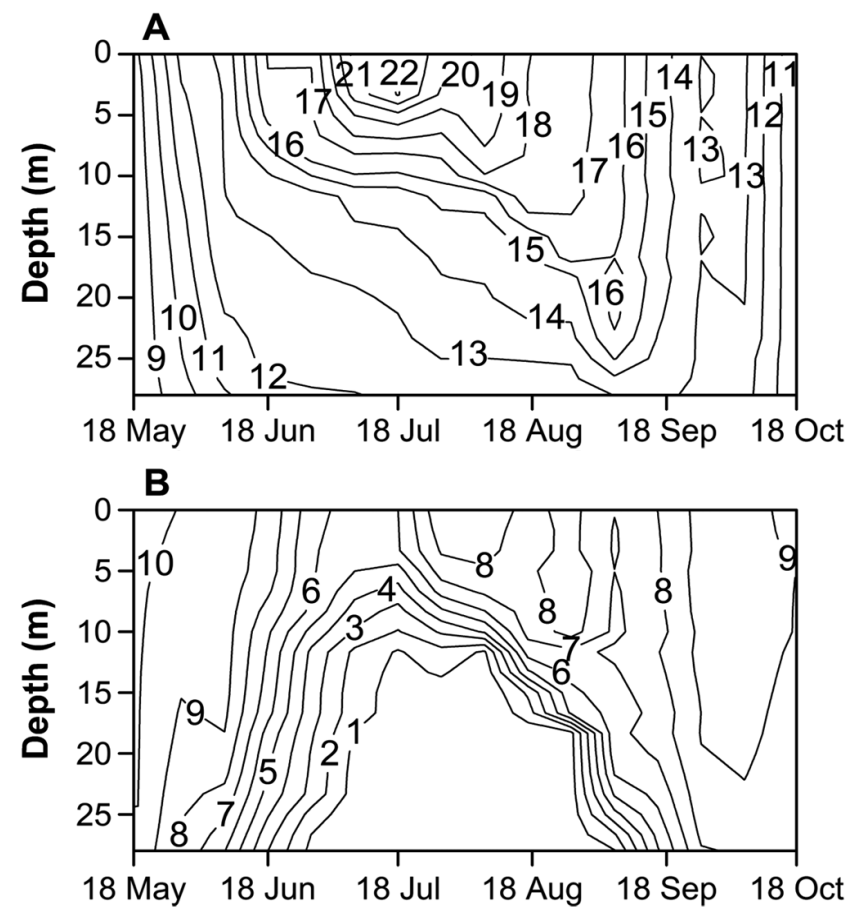

Fig. 1. (A) Temperature $\left({ }^{\circ} \mathrm{C}\right.$ ) and (B) oxygen concentrations $\left(\mathrm{mg} \mathrm{l}^{-1}\right)$ during the mixing period and stratification in Lake Vesijärvi in 2005
The latter temperature is high for a boreal lake. In late winter and early spring, the oxygen concentration throughout the water column was close to saturation $\left(10 \mathrm{mg} \mathrm{O}_{2} \mathrm{l}^{-1}\right)$, but development towards hypoxia and finally anoxia started in parallel with formation of thermal stratification (Fig. 1B). The oxygen concentration in the hypolimnion dropped below $1 \mathrm{mg} \mathrm{l}^{-1}$ in July and August. During stratification, hypoxia started from a depth of 6 to $7 \mathrm{~m}$ and anoxia from $14 \mathrm{~m}$. Thus, the hypoxia reached the bottom of the euphotic zone. The epilimnetic oxygen concentration was usually between 6 and $8 \mathrm{mg} \mathrm{l}^{-1}$, i.e. 80 to $100 \%$ saturation. The lowest oxygen concentrations at the surface were only about $5 \mathrm{mg} \mathrm{l}^{-1}$ and were recorded on 5 July, i.e. at the time of maximum surface temperatures. At the end of August, the stratification started to break down and anoxia eased. In autumn, the whole water column became oxygenated again, with concentrations of 9 to $10 \mathrm{mg} \mathrm{O}_{2} \mathrm{l}^{-1}$. Secchi depth (not shown) was between 1.5 and $2 \mathrm{~m}$ in the spring, but increased to $3.5 \mathrm{~m}$ in July. From $16 \mathrm{Au}-$ gust onwards, Secchi depth was approximately $2 \mathrm{~m}$.

Changes in nutrient concentrations reflected the development of stratification and especially the change in oxygen conditions. In general, the phosphorus and nitrogen concentrations were much lower in the epilimnion than in the hypolimnion (ANOVA: $\mathrm{n}=30, \mathrm{p}<$ 0.001 and $p=0.002$ for TN and TP, respectively) (Fig. 2). The epilimnetic phosphorus concentration dropped from $0.8-0.9 \mu \mathrm{M}$ at the onset of the stratification to the seasonal minimum of $0.6 \mu \mathrm{M}$ in mid-July at the time of strongest stratification. The concentration increased again in August in parallel with the thermocline deepening and reached $>1.1 \mu \mathrm{M}$ in October. Contrary to phosphorus concentration, there was a decreasing trend in the epilimnetic nitrogen concentration throughout the sampling period so that the concentration dropped from a maximum of ca. $39 \mu \mathrm{M}$ in May to $32 \mu \mathrm{M}$ in October. As a result of the contrasting seasonal patterns in nitrogen and phosphorus concentrations, the nitrogen:phosphorus ratio fluctuated from 62 in mid-July to 26 in late October, and thus, the epilimnion appeared to be phosphorus-limited throughout the season. The hypolimnetic phosphorus and nitrogen concentrations varied between 0.7 and $8.1 \mu \mathrm{M}$ and 31 and $416 \mu \mathrm{M}$, respectively, i.e. on average there was 4 times more phosphorus and 2.5 times more nitrogen in the hypolimnion than in the epilimnion (Fig. 2). Hypolimnetic nutrient concentrations increased markedly in August at the time of thermocline breakdown, but due to dilution, the phosphorus and nitrogen concentrations decreased to 1.1 and $31 \mu \mathrm{M}$, respectively, during autumn turnover. 

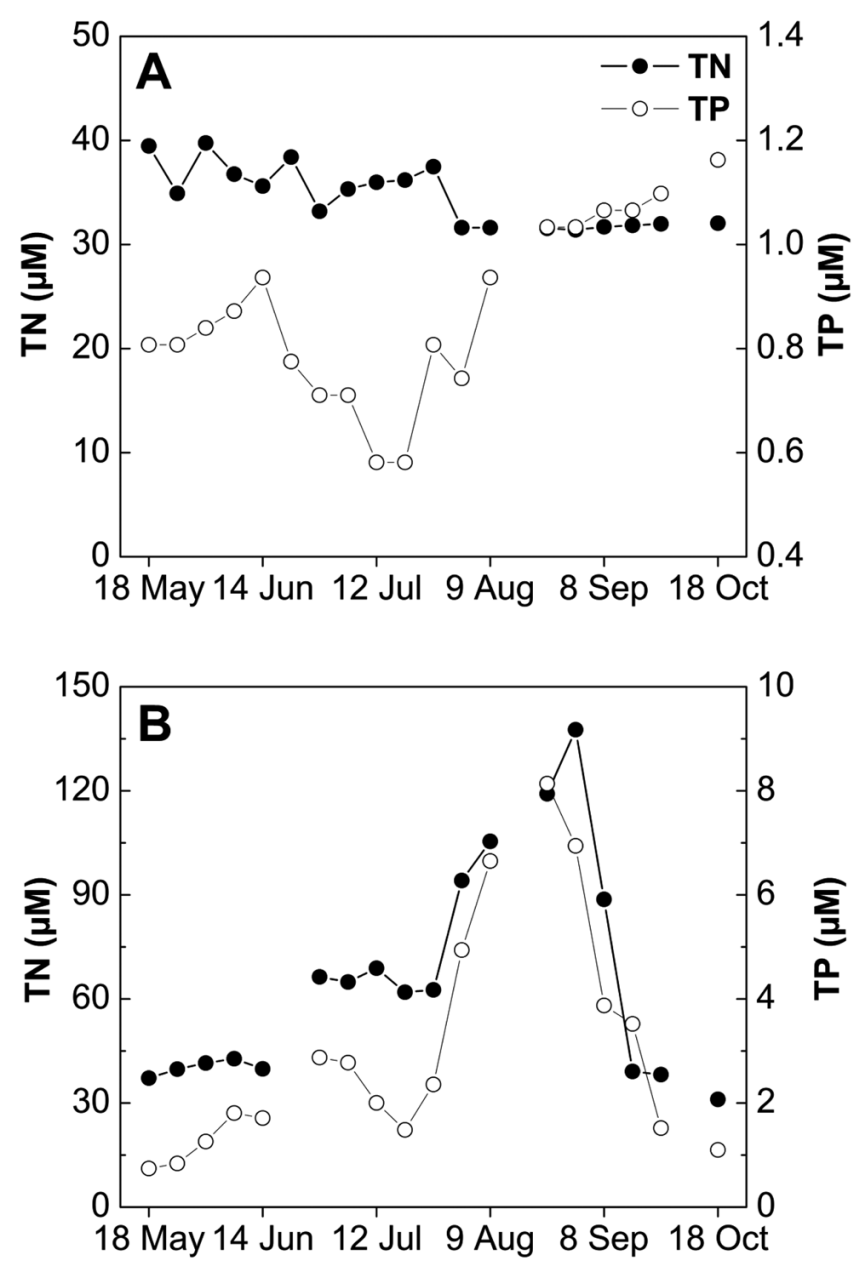

Fig. 2. Total dissolved phosphorus (TP) and nitrogen (TN) concentrations in water samples from (A) 0 to $5 \mathrm{~m}$ depth, representative of the epilimnion, and (B) 25 to $28 \mathrm{~m}$ depth, representative of the hypolimnion in Lake Vesijärvi in 2005

\section{Primary producers}

The epilimnetic concentration of chl a varied from

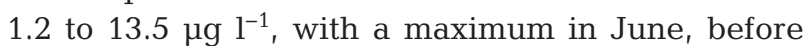
stratification, and with low concentrations at the time of the strongest stratification in July (Fig. 3). The mean and maximum concentrations of APP-derived chlorophyll were 1.3 and $4.2 \mu \mathrm{g} \mathrm{l}^{-1}$, respectively. An average $25 \%$ of the chlorophyll was in the APP fraction, but the contribution of APP varied in accordance with the stratification and total chlorophyll concentration such that in spring and autumn 3 to $5 \%$ of chlorophyll was from APP, whereas in midsummer, at the time of lowest chlorophyll concentration, the contribution of APP averaged $80 \%$.

In addition, the density of APP showed a clear seasonal and spatial pattern (Fig. 4). The seasonal dynamic was most pronounced in the epilimnion (ANOVA: $\mathrm{n}=63, \mathrm{p}=0.004$ ), where APP were numerous. The APP numbers increased simultaneously with the development of stratification, and the maximum epilimnetic cell number, $4.5 \times 10^{5} \mathrm{cells} \mathrm{ml}^{-1}$, was reached in early August, at the time of the strongest stratification. The population declined in mid-August, when the thermocline started to sink. The epilimnetic population in late summer and fall was similar in size to that in spring before the lake was stratified. APP could be found down to $15 \mathrm{~m}$, i.e. in the hypoxic zone, but not before the beginning of July, and the numbers were low relative to the epilimnion. Eukaryotic picoalgal cells were never recorded, i.e. only prokaryotic cyanobacterial cells were present. We observed both PC-rich and PEcontaining cells, but in general $85 \pm 10 \%( \pm \mathrm{SE})$ of cells were PC-rich. Seasonally, the relative importance of PC cells increased towards late August to ca. $90 \%$. Throughout the season, APP numbers were negatively correlated with phosphorus concentration (Table 1). Multiple regression analysis showed that $68 \%$ of the variance in APP abundance was predicted by the model including temperature, $\mathrm{chl} a$, PP and oxygen concentration (Table 2).

A clear seasonal pattern was also present in PP such that the rates at 0 to $5 \mathrm{~m}$ depth varied from 15 to $70 \mathrm{mg} \mathrm{C} \mathrm{m}{ }^{-3} \mathrm{~d}^{-1}$, with a mean value $( \pm \mathrm{SE})$ of $38 \pm 16 \mathrm{mg} \mathrm{C}$ $\mathrm{m}^{-3} \mathrm{~d}^{-1}$ (Fig. 3). Similar to chl a, PP was at a maximum in spring, with a mean rate of $54 \mathrm{mg} \mathrm{C} \mathrm{m}^{-3} \mathrm{~d}^{-1}$. After a drop, the production increased simultaneously with thermal stratification, reaching a maxi-
Fig. 3. Primary production (PP) and concentration of chl $a$, including the

contribution of autotrophic picoplankton (APP chl a), at 0 to $6 \mathrm{~m}$ depth in
Lake Vesijärvi in 2005. BP = bacterial production

contribution of autotrophic picoplankton (APP chl a), at 0 to 6
Lake Vesijärvi in 2005. BP = bacterial production

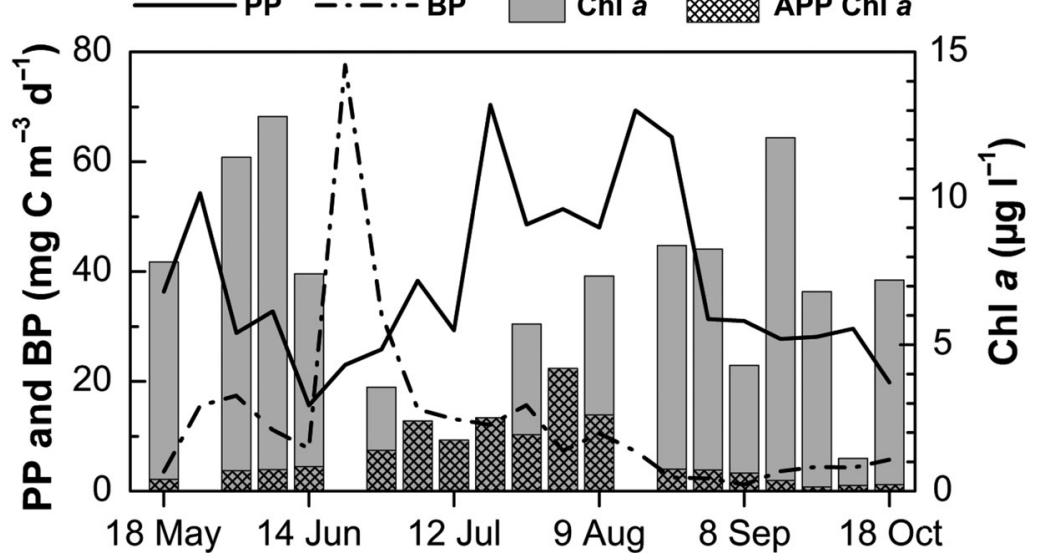



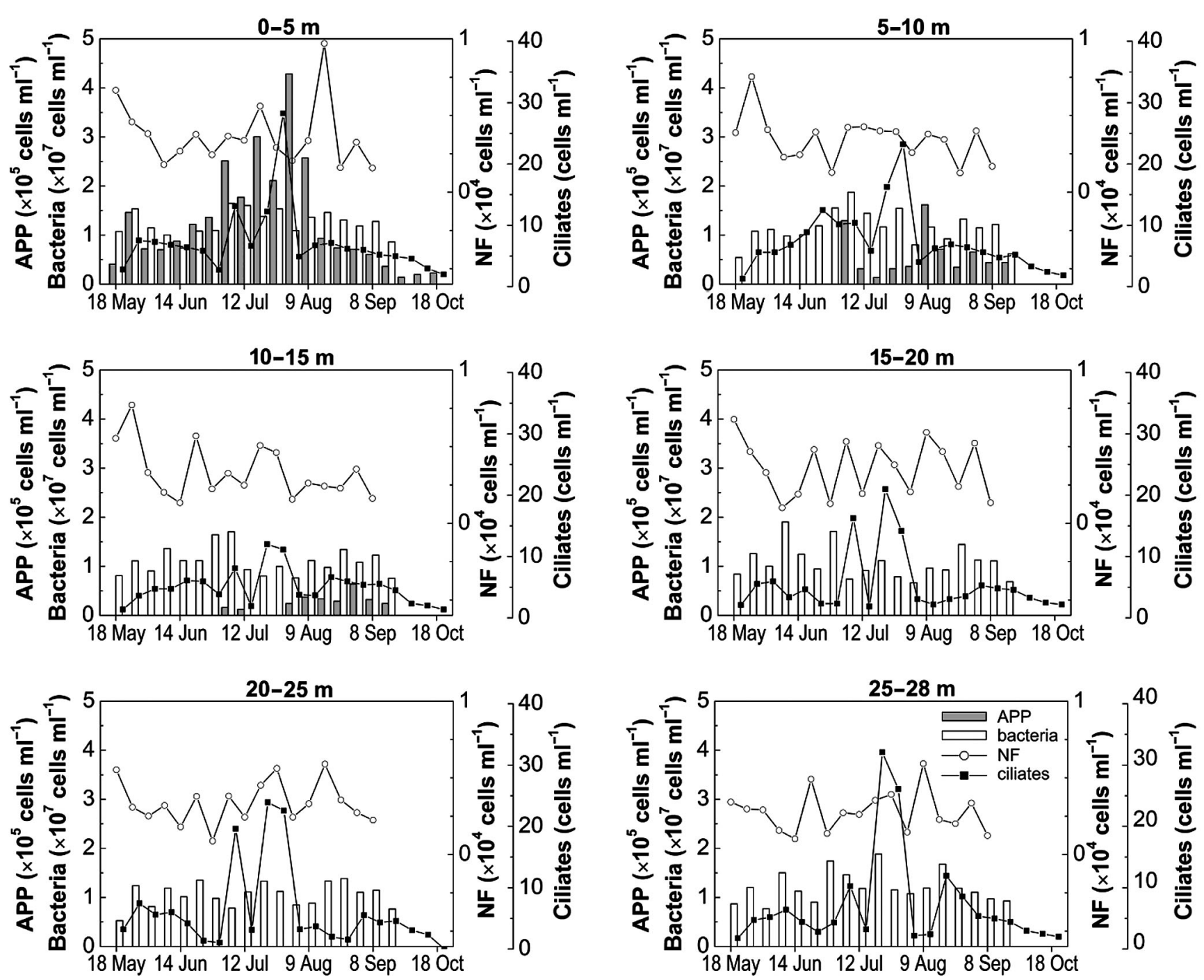

Fig. 4. Spatial (depth classes) and temporal distribution of autotrophic picoplankton (APP), bacteria, nanoflagellates (NF) and ciliates (note different axes for NF and ciliates) in Lake Vesijärvi in 2005

mum during and just after the maxima of APP, and thus, PP was strongly correlated with APP (Table 1). The midsummer productivity maximum of $70 \mathrm{mg} \mathrm{C}$ $\mathrm{m}^{-3} \mathrm{~d}^{-1}$ was recorded on 20 July, when the phytoplankton biomass was strongly dominated by APP. The PP halved in September, although, as a consequence of turnover, hypoxia eased off and hypolimnetic nutrients were mixed throughout the water column.

\section{Bacteria}

Bacterial density was on average $( \pm \mathrm{SE}) 1.1 \times 10^{7} \pm$ $1.1 \times 10^{6}$ cells $\mathrm{ml}^{-1}$, and it showed a bimodal pattern down to $20 \mathrm{~m}$ (Fig. 4). From the surface to $10 \mathrm{~m}$ depth, bacterial density was at a maximum during the strongest stratification, when the total amount of phytoplankton was at its lowest and the relative importance of APP greatest. At the onset of the autumn mixing period, the number of bacteria decreased. In general, there were approximately 100 times more bacterial than APP cells in the epilimnion. In contrast to the epilimnion, down to $20 \mathrm{~m}$ depth, the first maximum in bacterial cell numbers was at the time of spring mixing. Below 20 m, seasonal fluctuations were more sporadic. Bacterial densities were the same throughout the water column, except at the time of stratification, when more bacterial cells were present in the epilimnion than in the hypolimnion (ANOVA: $\mathrm{n}=36, \mathrm{p}=0.015$ ).

$\mathrm{BP}$ in the epilimnion usually varied from 2 to $17 \mathrm{mg}$ $\mathrm{C} \mathrm{m} \mathrm{m}^{-3} \mathrm{~d}^{-1}$, but we observed a clear maximum of $80 \mathrm{mg} \mathrm{C} \mathrm{m}^{-3} \mathrm{~d}^{-1}$ on 20 June, i.e. simultaneously with 
Table 1. Pearson linear correlation coefficients (r) and level of significance for numbers of autotrophic picoplankton (APP), bacteria, nanoflagellates (NF) and ciliates; primary production (PP); chl a concentration; bacterial production $(\mathrm{BP})$; concentration of total phosphorus $(\mathrm{TP})$; as well as temperature, oxygen concentration and $\mathrm{pH}$ in Lake Vesijärvi in 2005. ${ }^{*} \mathrm{p}<0.05,{ }^{* *} \mathrm{p}<0.01,{ }^{* * *} \mathrm{p}<0.001$

\begin{tabular}{|c|c|c|c|c|c|c|c|c|}
\hline & & APP & Bacteria & $\mathrm{NF}$ & Ciliates & PP & Chl a & $\mathrm{BP}$ \\
\hline \multirow[t]{2}{*}{ APP } & $\mathrm{r}$ & & $0.29^{*}$ & & & $0.77^{* * *}$ & $0.39^{* * *}$ & $0.46^{* *}$ \\
\hline & $\mathrm{n}$ & & 108 & & & 126 & 115 & 38 \\
\hline \multirow[t]{2}{*}{ Bacteria } & $\mathrm{r}$ & $0.23^{*}$ & & & $0.28^{* *}$ & $0.22^{*}$ & & \\
\hline & $\mathrm{n}$ & 108 & & & 108 & 108 & & \\
\hline \multirow[t]{2}{*}{ NF } & $\mathrm{r}$ & & & & & & & \\
\hline & $\mathrm{n}$ & & & & & & & \\
\hline \multirow[t]{2}{*}{ Ciliates } & $\mathrm{r}$ & & $0.28^{* *}$ & & & & & $0.58^{* *}$ \\
\hline & $\mathrm{n}$ & & 108 & & & & & 19 \\
\hline \multirow[t]{2}{*}{ PP } & $\mathrm{r}$ & $0.77^{* * *}$ & $0.22^{*}$ & & & & $0.55^{* * *}$ & \\
\hline & $\mathrm{n}$ & 126 & 108 & & & & 115 & \\
\hline \multirow[t]{2}{*}{ Chl a } & $\mathrm{r}$ & $0.39^{* * *}$ & & & & $0.55^{* * *}$ & & \\
\hline & $\mathrm{n}$ & 115 & & & & 115 & & \\
\hline \multirow[t]{2}{*}{ BP } & $\mathrm{r}$ & $0.46^{* *}$ & & & $0.58^{* *}$ & & & \\
\hline & $\mathrm{n}$ & 38 & & & 19 & & & \\
\hline \multirow[t]{2}{*}{ TP } & $\mathrm{r}$ & $-0.66^{*}$ & & & & & & $-0.57^{*}$ \\
\hline & $\mathrm{n}$ & 15 & & & & & & 15 \\
\hline \multirow[t]{2}{*}{ Temperature } & $\mathrm{r}$ & $0.60^{* * *}$ & $0.30^{* *}$ & & $0.27^{* *}$ & $0.41^{* *}$ & $0.22^{*}$ & \\
\hline & $\mathrm{n}$ & 126 & 108 & & 126 & 126 & 115 & \\
\hline \multirow[t]{2}{*}{ Oxygen } & $\mathrm{r}$ & & & & $-0.31^{* * *}$ & $0.24^{* *}$ & $0.42^{* * *}$ & \\
\hline & $\mathrm{n}$ & & & & 126 & 126 & 115 & \\
\hline \multirow[t]{2}{*}{$\mathrm{pH}$} & $\mathrm{r}$ & & & & $-0.27^{* *}$ & $0.33^{* * *}$ & $0.43^{* * *}$ & \\
\hline & $\mathrm{n}$ & & & & 126 & 126 & 115 & \\
\hline
\end{tabular}

Table 2. Multiple linear regression model exploring the variables that predict the abundance of autotrophic picoplankton (APP), bacteria, nanoflagellates (NF) and ciliates in Lake Vesijärvi in 2005. $\mathrm{n}=97$

\begin{tabular}{|c|c|c|c|c|c|}
\hline Abundance & $\begin{array}{l}\text { Adjusted } \\
\mathrm{R}^{2}\end{array}$ & $\begin{array}{c}\text { Model } \\
\text { significance }\end{array}$ & $\alpha$ & Factor & Slope \\
\hline $\log ($ Ciliates $)$ & 0.16 & 0.02 & -5.94 & $\begin{array}{l}\text { Temperature } \\
\log (\text { Bacteria }) \\
\log (N F)\end{array}$ & $\begin{array}{l}0.02 \\
0.74 \\
0.32\end{array}$ \\
\hline $\log (\mathrm{NF})$ & 0.08 & 0.04 & 7.70 & $\begin{array}{l}\log (\text { Bacteria }) \\
\log (\text { Ciliates })\end{array}$ & $\begin{array}{r}-0.62 \\
0.16\end{array}$ \\
\hline $\log$ (Bacteria) & 0.18 & 0.01 & 7.29 & $\begin{array}{l}\text { Temperature } \\
\log (\text { Ciliates }) \\
\log (N F)\end{array}$ & $\begin{array}{r}0.01 \\
0.09 \\
-0.12\end{array}$ \\
\hline $\log (\mathrm{APP})$ & 0.68 & 0.03 & -4.52 & $\begin{array}{l}\text { Temperature } \\
\text { Chl a } \\
\text { PP } \\
\text { Oxygen }\end{array}$ & $\begin{array}{l}0.35 \\
0.14 \\
0.04 \\
0.09\end{array}$ \\
\hline
\end{tabular}

low PP and a drop in chl a (Fig. 3). Also, 1 wk later, the rates of production were high, indicating that the peak was a real phenomenon and not a measuring error. After the maximum, BP sharply decreased to levels similar to the ones recorded in spring. In general, in spring and summer, BP followed the changes in APP numbers (Table 1). In autumn, when the lake started to mix, APP densities decreased and BP dropped to $4.5 \mathrm{mg} \mathrm{C} \mathrm{m} \mathrm{m}^{-3} \mathrm{~d}^{-1}$. The number of bacteria was related to PP (Table 1) and this correlation was most obvious during the spring mixing period (Fig. 3). Similar to APP, BP showed a negative correlation with phosphorus (Table 1). Multiple regression showed that temperature and abundance of ciliates and NF were significantly correlated with bacterial numbers, but the model explained only $18 \%$ of variance in abundance (Table 2).

\section{Protozoa}

The densities of NF ranged between $0.9 \times 10^{3}$ and $9.7 \times 10^{3}$ cells ml ${ }^{-1}$, with a mean of $3.4 \times 10^{3}$ cells ml $^{-1}$ (Fig. 4). At 0 to $5 \mathrm{~m}$ depth, the densities were highest in May, during the mixing period, and again in mid-August, at the onset of thermocline deepening. During stratification, the epilimnetic densities were fairly stable and low, with a mean value of $3.1 \times 10^{3}$ cells $\mathrm{ml}^{-1}$. NF were less abundant at the beginning of June, when the total amount of phytoplankton was high, but APP and bacteria were infrequent. NF increased simultaneously with a decrease of ciliate numbers in late summer. The spring peak of NF was visible down to $25 \mathrm{~m}$, whereas the late summer peak did not show up below the epilimnion. From 5 to $15 \mathrm{~m}$ depth, there was a declining seasonal trend in NF numbers, whereas deeper down in the anoxic layers the numbers were negatively correlated with bacteria abundance (Pearson: $\mathrm{p}=0.008, \mathrm{n}=68$, $r=-0.321$ ). Except for the uppermost $5 \mathrm{~m}$ water layer, NF showed no apparent responses to water-column mixing. Also, the differences between NF numbers from oxygenated and hypoxic waters were non-significant (ANOVA: $\mathrm{p}=0.67, \mathrm{n}=101$ ). Multiple regression related NF to abundance of bacteria and ciliates, but the model explained only $8 \%$ of the variance in NF numbers (Table 2).

The mean $( \pm \mathrm{SE})$ number and biomass of ciliates were $6.3 \pm 5.1$ cells $\mathrm{ml}^{-1}$ and $121 \pm 70.6 \mu \mathrm{g}$ wet wt $\mathrm{l}^{-1}$, respectively. In terms of cell numbers, the ciliates were most abundant in late July, during the stratifi- 
cation period (mean: $21 \pm 6.8$ cells ml$^{-1}$ ), when the epilimnetic concentrations of APP and bacteria were highest, whereas the highest mean biomass was attained in surface waters in early summer during the mixing period $\left(250 \pm 228 \mu \mathrm{g}\right.$ wet wt $\left.\mathrm{l}^{-1}\right)$. The midsummer peak of ciliate abundance reached down to the very bottom, i.e. from oxic to hypoxic conditions and finally to anoxic water layers. In general, the seasonal dynamic was similar throughout the water column (ANOVA: $\mathrm{n}=125, \mathrm{p}=0.69$ ). The total number of ciliates fluctuated weakly $(16 \%)$ in relation to temperature and the number of bacteria and NF (Table 2).

Although the overall seasonal dynamic did not vary vertically, the community composition of ciliates varied greatly with depth and oxygen conditions.
Throughout the sampling period, the community consisted of 9 groups: oligotrichs, choreotrichs, haptorids, scuticociliates, hymenostomes, prostomatids, plagiopylids, peritrichs and hypotrichs (Fig. 5). Altogether, 22 ciliate genera were found and 10 species were recognised. During spring mixing, the surface community consisted of oligotrichs, haptorids, prostomatids and peritrichs, whereas during stratification the epilimnetic community was dominated by prostomatids (Balanion planktonicum, Coleps sp. and Urotricha sp.) together with some oligotrichs. Consequently, the density of prostomatids correlated with the cell density of APP, but also with bacteria (Pearson: $\mathrm{p}<0.001, \mathrm{n}=21, \mathrm{r}=0.22$, and $\mathrm{p}=0.02, \mathrm{n}=18$, $\mathrm{r}=0.35$, respectively). Some raptorial feeding prostomatids (B. planktonicum) and haptorids (Askenasia

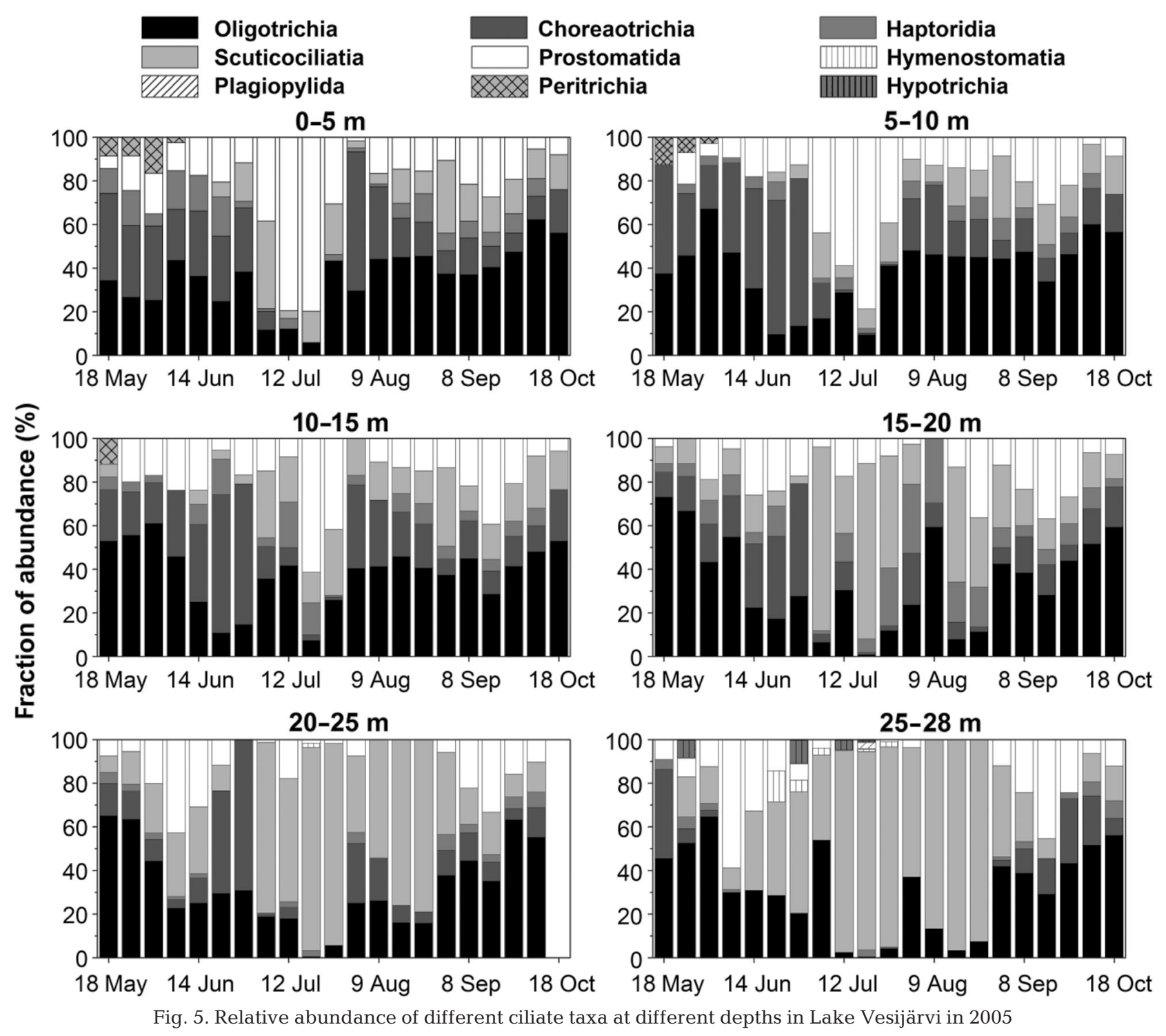


volvox) were positively correlated with NF numbers in the epilimnion (Pearson: $\mathrm{p}<0.04, \mathrm{n}=18, \mathrm{r}=0.50$ and $\mathrm{p}=0.03, \mathrm{n}=18, \mathrm{r}=0.54$, respectively). When the stratification was breaking up in the autumn and the lake began to mix, the community was dominated by oligotrichs, which also showed a positive correlation with primary producers (APP: $\mathrm{r}=0.22, \mathrm{p}=0.01, \mathrm{n}=$ 21; PP: $\mathrm{r}=0.23, \mathrm{p}=0.01, \mathrm{n}=21$; chl $a: \mathrm{r}=0.31, \mathrm{p}<$ $0.001, \mathrm{n}=18$ ). The dominance of prostomatids during stratification reached down to $10 \mathrm{~m}$ and also the hypoxic zone in the depth class 10-15 m. In the anoxic conditions, prostomatids were replaced by scuticociliates, which dominated until the hypolimnetic waters became mixed. The abundance of scuticociliates strongly correlated with bacteria numbers (Pearson: $\mathrm{p}=0.02, \mathrm{n}=63, \mathrm{r}=0.53$ ).

During the mixing periods there was no zonation in the ciliate community, and the representatives of oligotrichs (Pelagostrobidium sp. and Rimostrombidium spp.), haptorids (Askenasia volvox), choreotrichs (Tintinnidium fluviatile and Codonella cratera) and some scuticociliates were found throughout the water column (Fig. 6). During stratification, the diversity at the genus level differed significantly between the oxic and anoxic zone ( $t$-test: $\mathrm{p}<0.001, \mathrm{n}=21$ ). It decreased from 2.0 to 0.3 in the hypolimnion, while in the epilimnion the Shannon-Wiener index was about $1.9 \pm 0.3( \pm \mathrm{SE})$ throughout the growing period. The epilimnetic and hypolimnetic communities differed considerably. The bacterivorous ciliates Cinetochilum margaritaceum, Cyclidium sp. and Uronema sp. were abundant below $15 \mathrm{~m}$, i.e. in anoxic conditions, whereas the epilimnetic picophages belonged to the genera Limnostrombidium and Rimostrombidium. Algivorous ciliates were mainly Balanion planktonicum and Urotricha sp., although $A$. volvox was also observed, not only in the oxic zone, but also in hypoxic and anoxic waters. Predatory haptorids (Didinium sp., Dileptus sp., Lacrymaria olor and Paradileptus elephantinus) were present in summer in the oxic water layers, while Trimyema compressum-an anaerobic ciliate capable of carrying methanogenic endosymbiotic microbes-was occasionally found in the hypolimnion.

\section{CCA}

The model obtained from the CCA on ciliate community composition explained nearly $80 \%$ of the variation in the data. The first eigenvalue presented on Axis 1 accounted for $48.65 \%$ of the overall variability and was related to $\mathrm{pH}$ and oxygen concen- tration. The second eigenvalue, which explained $31.33 \%$ of the variation, appeared on Axis 2 and was related to water temperature, APP and PP. The samples from the mixing period in spring and early summer as well as the samples from the hypolimnion and epilimnion formed clear clusters showing distinct communities present in oxic and hypoxic/anoxic water layers (Fig. 7A). Therefore, the ciliate community composition was clearly related to the water column depth and seasonal changes in environment (Fig. 7B). Filter-feeding ciliates (Pelagostrombidium sp., Tintinnidium fluviatile, Vorticella sp. and small prostomatids) grazing on nano- and pico-sized prey were related to mixing periods, when the whole water column was oxic and fairly cool. Larger algivorous (Codonella cratera and Urotricha sp.) and predatory (Dileptus sp., Lacrymaria olor and Paradileptus elephantinus) ciliates were related to the oxic epilimnion during stratification, when water temperatures and PP were high and APP abundant. Scuticociliates, but also Hymenostomatia and Trimyema compressum, were related to samples from the period, when hypolimnion remained depleted in oxygen.

\section{DISCUSSION}

Seasonal changes in dissolved oxygen concentration and temperature shaped the ciliate community and strongly influenced the microbial food web in Lake Vesijärvi. Ciliates displayed clear differing patterns in diversity over the mixing and stratification periods (Fig. 6). During summer stratification, a distinct protozoan community, separated by an oxycline, developed within the water column: herbivorous species having access to photosynthetic algae dominated in the epilimnion, while filter-feeding bacterivores prevailed in the hypolimnion. However, the vertical distribution patterns disappeared as soon as stratification broke down and oxygen was mixed down to the bottom of the lake.

The results on the importance of oxygen for structuring ciliate community composition (Fig. 7) are in agreement with previous studies reporting zonation patterns of ciliates in stratified lakes with an anoxic hypolimnion (Fenchel et al. 1990, Guhl et al. 1994, Gobler et al. 2008). Different anoxic environments are often inhabited by similarly structured ciliate communities. A stable physicochemical environment, low growth efficiency of heterotrophic bacteria and anaerobic protozoa as well as low metazoan grazing pressure in the anoxic zone creates the near-steady-state condi- 

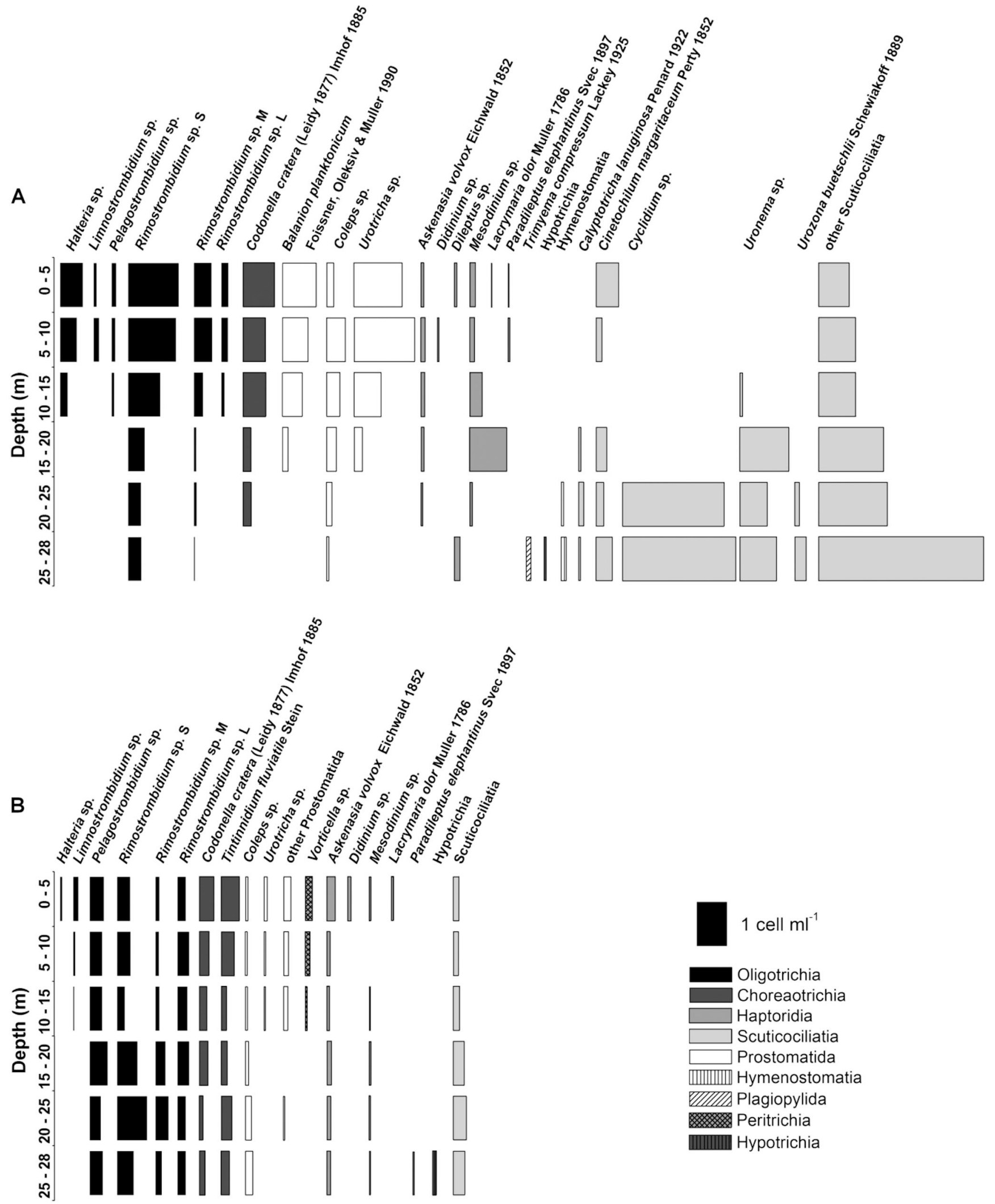

Fig. 6. Vertical distribution pattern of ciliates shown as cells $\mathrm{ml}^{-1}$ during the (A) stratification and (B) mixing periods. Ciliate abundances displayed here are mean values for May and October (mixing period) and July and August (stratification). S, M, L: small, medium, large 

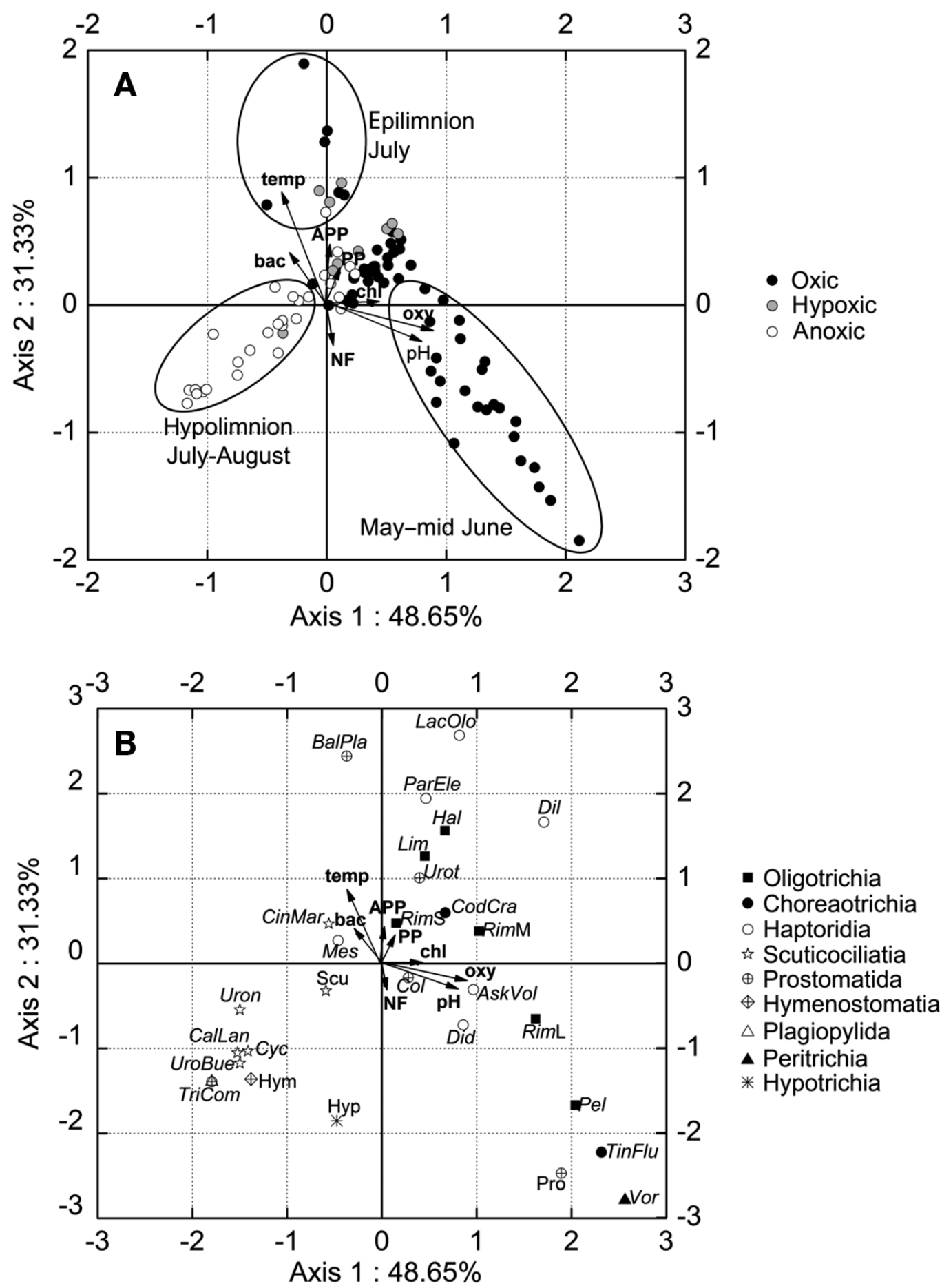

Fig. 7. Biplot of canonical correspondence analysis based on ciliate abundance data showing the relationships between environmental variables and (A) samples, as well as (B) ciliate species composition in Lake Vesijärvi. The eigenvalues of the axes are shown in the ordination. APP $=$ autotrophic picoplankton, AskVol $=$ Askenasia volvox, bac $=$ bacteria, BalPla $=$ Balanion planktonicum, CalLan = Calyptotricha lanuginosa, $\mathrm{chl}=$ chlorophyll, CinMar $=$ Cinetochilum margaritaceum, CodCra $=$ Codonella cratera, $C o l=$ Coleps sp., Cyc $=$ Cyclidium sp., Did = Didinium sp., Dil = Dileptus sp., Hal = Halteria sp., Hym = Hymenostomatia, Hyp = Hypotrichia, LacOlo = Lacrymaria olor, Lim = Limnostrombidium $\mathrm{sp} .$, Mes $=$ Mesodinium $\mathrm{sp} ., \mathrm{NF}=$ nanoflagellates, oxy = oxygen, ParEle = Paradileptus elephantinus, Pel = Pelagostrombidium sp., PP = primary production, Pro $=$ other Prostomatida, RimL $=$ Rimostrombidium sp. large, RimM $=$ Rimostrombidium sp. medium, RimS $=$ Rimostrombidium sp. small, Scu = other Scuticociliates, temp = temperature, TinFlu = Tintinnidium fluviatile, TriCom = Trimyema compressum, UroBue $=$ Urozona buetschii, Uron $=$ Uronema sp., Urot $=$ Urotricha sp. and Vor $=$ Vorticella sp. 
tions responsible for the development of vertical distribution patterns (Guhl et al. 1996). In accordance with our hypothesis, we found a less diverse ciliate community in the oxygen-depleted zone. Guhl et al. (1994) suggested that the low number of habitat niches and low food diversity in anoxic parts of the water column are responsible for an observed decrease in ciliate diversity.

We found high numbers of scuticociliates together with some oligotrichs and prostomatids in the anaerobic zones of Lake Vesijärvi (Fig. 5). The dominance of scuticociliates in the hypolimnion is attributed to their considerable tolerance of anoxia (Fenchel et al. 1990) and a high abundance of bacteria. The occasional presence of oligotrichs and prostomatids in the hypoxic zone is usually possible due to symbiotic algae supplying oxygen (Esteve et al. 1988). Many ciliates of the anoxic zone harbour other type of symbionts - methanogenic Archaeawhich use hydrogen produced by the ciliate host (Fenchel \& Finlay 1992). Although the abundance of ciliate species capable of hosting methanogenic endosymbionts, i.e. Trimyema compressum (Shinzato et al. 2007), was low in Lake Vesijärvi (<1 ind. $\mathrm{ml}^{-1}$ ), the methane concentration in the hypolimnion of the lake is high, indicating the importance of methane in the carbon mineralisation pathway (López Bellido et al. 2011). Especially in boreal lakes, the methane oxidation pathway is important in carbon transfer (Taipale et al. 2008). On the other hand, high nutrient concentrations and temperature in the hypolimnion of Lake Vesijärvi suggest that, besides methanogens and methanotrophs, nitrifiers and sulphur and iron oxidisers may also be present. Thus, in the hypolimnion of Lake Vesijärvi, the environmental conditions seem to favour an abundant and diverse bacterial community. Bacterivorous ciliates require bacterial concentrations of $10^{6}$ cells $\mathrm{ml}^{-1}$ to sustain growth (Sherr et al. 1989) and, in Lake Vesijärvi, hypolimnetic bacterial abundances up to $1.9 \times 10^{7}$ cells $\mathrm{ml}^{-1}$ provide a vast food source for the bacterivorous protozoa.

While the ciliate communities in hypoxic zones have, in general, many similarities, the epilimnetic populations may differ considerably (Guhl et al. 1996). In Lake Vesijärvi, the epilimnetic community composition of ciliates was typical of freshwater (Zingel et al. 2007), with a dominance of large algivores, mainly prostomatids (Balanion planktonicum, Coleps sp. and Urotricha sp.) and oligotrichs (Rimostrombidium spp. and Halteria sp.) (Fig. 6). The occurrence of both classes is strongly controlled by the distribution of algal food sources (Müller et al.
1991), but is also regulated by oxygen concentration (Fenchel et al. 1990). Algivorous ciliates have a tendency to swim upwards and to concentrate in the upper water layers, occurring in water with above 30 to $40 \%$ of atmospheric oxygen saturation (Jonsson 1989). During stratification, algivorous species resided in the epilimnion, but as soon as mixing distributed oxygen throughout the whole water column, they were found in the bottom of the lake. Large oligotrichs were numerous during periods of maximum chlorophyll concentration, while small, filter-feeding oligotrichs and prostomatids were most common, when the phytoplankton biomass was dominated by pico-sized cells. At the same time the total number of ciliates was closely coupled with the number and productivity of bacteria (Table 1). The positive relationship between prey and predator implies a possible growth of predator in response to ample prey (e.g. Pace 1982), and food availability and/or temperature may influence seasonal dynamics of the ciliate community (Hamels et al. 2005). Zingel et al. (2007) also suggested that the abundance and composition of the ciliate community is driven by food resources. Moreover, lack of significant correlation between NF and picoplankton (Table 1) in the oxic zone suggests that in the epilimnion of Lake Vesijärvi, ciliates constitute an important link to both large algae and the picoplankton community. A similar shift towards ciliatedominated grazing has been observed in eutrophic systems (Zingel et al. 2007).

Although the highest numbers of NF were recorded during APP peaks (Fig. 4), and our previous study revealed the ability of NF from Lake Vesijärvi to graze on APP (Bręk-Laitinen \& Ojala 2011), the statistical comparison showed no general NF linkage to the food resources (Table 1). Despite the significant role of NF as consumers of bacteria (Šimek et al. 1997), only part of NF are really bacterivorous, with large species being primary algivorous (Sherr \& Sherr 2002), while one-third of NF can be mixotrophic (Bennett et al. 1990). Therefore, the lack of NF coupling with picoplankton could be due to a high degree of NF mixotrophy.

In the anaerobic zone, NF populations are usually sparser than in oxygenated surface waters (Fenchel et al. 1990), but they readily graze on bacteria (Choi et al. 1999), as oxygen concentrations down to $0.1 \%$ of saturation should not affect their activity (Fenchel \& Finlay 1995). We found no significant differences between NF numbers from oxygenated and hypoxic waters, and a negative correlation between NF and bacteria in the hypolimnion. Relatively stable NF 
abundance throughout the water column and no coupling with food resources (Fig. 4, Table 1) indicates a high importance of other factors besides food in controlling NF dynamics. Similar results in some eutrophic lakes are explained by the strong predator pressure (Weisse 1991), which becomes important especially in summer (Psenner \& Sommaruga 1992). The positive relationships between NF and some ciliate species in the epilimnion suggest that ciliates may be involved in the top-down control of NF (Weisse 1991). In Lake Vesijärvi, besides ciliates, NF can be controlled by metazooplankton, which includes cladoceran species (Daphnia spp.) (Vakkilainen et al. 2010) capable of imposing a strong grazing pressure on protozoa (Jürgens et al. 1996). Vakkilainen et al. (2010) reported patterns of cladocera abundance that were exactly opposite to ciliate seasonal dynamics.

In Lake Vesijärvi, BP was related to APP and there was also an association between bacterial numbers, PP and APP (Table 1). Despite a lack of correlation between BP and chl a concentration, a close coupling between bacteria and phytoplankton cannot be ruled out. Phytoplankton releases up to $80 \%$ of the photosynthetically fixed carbon as extracellular DOC (Malinsky-Rushansky \& Legrand 1996). The efficiency of uptake and utilisation of algal DOC by bacteria depends on the phytoplankton community composition, with high uptake rates of APP-derived carbon (Malinsky-Rushansky \& Legrand 1996). During stratification, when nutrient limitation is strongest, small, efficient APP cells can outcompete larger phytoplankton and become abundant in the epilimnion (Callieri 2008). In Lake Vesijärvi, the contribution of APP to phytoplankton reaches $80 \%$ (present study) and the percentage of extracellular release is up to $50 \%$ (G. Bręk-Laitinen unpubl.). The high rate of extracellular organic carbon excretion usually results from phosphorus limitation-which was the case in Lake Vesijärviand promotes bacterial growth (Mindl et al. 2005). Thus, exceptionally high numbers of bacteria in the studied lake (Fig. 4) may have been due to high amounts of phytoplankton-derived dissolved organic matter (Søndergaard et al. 1995). The relative steadiness of bacterial numbers in both space and time is explained by the combination of the physical (Allen 1969) and chemical properties (De Wever et al. 2005) of the water column, with several biotic factors such as competition or predator-prey relationships (cf. Craig 1987). Therefore, in the epilimnion of Lake Vesijärvi, strong stratification leads to a situation similar to marine environments, where the microbial food web is a fairly closed system with most of the autotrophic PP respired in the photic layer by bacteria (Pomeroy 2001).

The apparent lack of coupling between bacterial numbers and BP in Lake Vesijärvi could be attributed to the common phenomenon of a large fraction of bacterial cells being either dead or dormant and so not participating in production (Chróst \& Rai 1994), as shown also by E. Peltomaa (unpubl. data) in her studies on Lake Vesijärvi. Additionally, selective grazing on remaining active bacteria could increase the relative stability of bacterial abundance in relation to changes in BP (Chróst \& Rai 1994). An extremely high late-spring peak in BP (Fig. 3) was the reason that there was no statistical correlation between BP and PP. The spring peak was 3 times higher than the corresponding PP and was a sporadic event after unusually high precipitation and resulting delivery of allochthonous DOC from catchment. Otherwise, BP in summer was ca. $22 \%$ of PP, which according to Cole et al. (1988) indicates a strong dependence of the bacterial community on phytoplankton production.

As hypothesised, the ciliate community responded dramatically to changes in oxygen concentration and temperature by creating a characteristic species distribution pattern along the water column. In the oxic epilimnion, the high biomass and productivity of phytoplankton resulted in the most common ciliates being large algivores and omnivores, while the abundance of small bacterivorous species was a reflection of a high BP. The decrease in ciliate diversity in the anaerobic zone proved that anoxia evoked changes in community composition. However, in contrast to our hypothesis, NF were not related to picoplankton and their numbers were stable in the whole water column. The relationship between APPdominated phytoplankton and bacteria in Lake Vesijärvi indicates that APP may be an important source of carbon for bacteria. Studies of the rate of production of dissolved compounds and in situ grazing rates, especially on ciliates, are needed in order to answer the question about carbon transfer from phytoplankton to bacteria and trophic relationships within this microbial community.

Acknowledgements. This research was supported by the Maj and Tor Nessling Foundation (no. 2005269). We thank E. Peltomaa for assistance in the field and with laboratory work. We are grateful to P. Zingel, who counted the ciliate samples and to I. Jasser, who critically read and improved the first version of the manuscript. D. Fewer and C. A. Pelli kindly edited the language. We thank the anonymous reviewers for their helpful comments. 


\section{LITERATURE CITED}

Allen KR (1969) Limitations on production in salmonid populations in streams. In: Northcote TG (ed) Symposium on salmon and trout in streams. University of British Columbia, Vancouver, p 3-18

Anderson OR (1987) Comparative protozoology. Springer Verlag, New York, NY

> Azam F, Fenchel T, Field JG, Gray JS, Meyer-Reil LA, Thingstad F (1983) The ecological role of water-column microbes in the sea. Mar Ecol Prog Ser 10:257-263

Bennett SJ, Sanders RW, Porter KG (1990) Heterotrophic, autotrophic, and mixotrophic nanoflagellates: seasonal abundances and bacterivory in a eutrophic lake. Limnol Oceanogr 35:1821-1832

Bergström I, Heinänen A, Salonen K (1986) Comparison of acridine orange, acriflavine, and bisbenzimide stains for enumeration of bacteria in clear and humic waters. Appl Environ Microbiol 51:664-667

> Bręk-Laitinen G, Ojala A (2011) Grazing of heterotrophic nanoflagellates on the eukaryotic picoautotroph Choricystis sp. Aquat Microb Ecol 62:49-59

- Callieri C (2008) Picophytoplankton in freshwater ecosystems: the importance of small-sized phototrophs. Freshw Rev 1:1-28

Choi DH, Na SC, Park YC, Huh SH, Cho BC (1999) Characteristics of microbial abundances in hypoxic water of brackish Lake Shihwa. J Korea Soc Oceanogr 34: 236-240

Chróst RJ, Rai H (1994) Bacterial secondary production. In: Overbeck J, Chróst RJ (ed) Microbial ecology of Lake Plußsee. Springer, New York, NY, p 93-117

$>$ Cole JJ, Findlay S, Pace ML (1988) Bacterial production in fresh and saltwater ecosystems: a cross-system overview. Mar Ecol Prog Ser 43:1-10

Craig SR (1987) The distribution and contribution of picoplankton to deep photosynthetic layers in some meromictic lakes. Acta Acad Aboensis 47:55-81

Davis PG, Sieburth JMcN (1982) Differentiation of phototrophic and heterotrophic nanoplankton populations in marine waters by epifluorescence microscopy. Ann Inst Oceanogr 58:249-260

$>$ De Wever A, Muylaert K, Van der Gucht K, Pirlot S and others (2005) Bacterial community composition in Lake Tanganyika: vertical and horizontal heterogeneity. Appl Environ Microbiol 71:5029-5037

> Diaz RJ (2001) Overview of hypoxia around the world. J Environ Qual 30:275-281

Diaz RJ, Rosenberg R (2008) Spreading dead zones and consequences for marine ecosystems. Science 321:926-929

- Eby LA, Crowder LB, McClellan CM (2005) Habitat degradation from intermittent hypoxia: impacts on demersal fishes. Mar Ecol Prog Ser 291:249-261

Esteve I, Gaju JMN, McKhann H, Margulis L (1988) Green endosymbiont of Coleps from Lake Ciso indentified as Chlorella vulgaris. Symbiosis 3:197-210

Fenchel T, Finlay BJ (1992) Production of methane and hydrogen by anaerobic ciliates containing symbiotic methanogens. Arch Microbiol 157:475-480

Fenchel T, Finlay BJ (1995) Ecology and evolution in anoxic worlds. Oxford University Press, Oxford

Fenchel T, Finlay BJ (2008) Oxygen and the spatial structure of microbial communities. Biol Rev Camb Philos Soc 83: 553-569

Fenchel T, Kristensen LD, Rasmussen L (1990) Water col- umn anoxia: vertical zonation of planktonic protozoa. Mar Ecol Prog Ser 62:1-10

Finlay BJ, Esteban GF (1998) Planktonic ciliate species diversity as an integral component of ecosystem function in a freshwater pond. Protist 149:155-165

Finlay BJ, Maberly SC, Cooper JI (1997) Microbial diversity and ecosystem function. Oikos 80:209-213

Foissner W, Berger H (1996) A user-friendly guide to the ciliates (Protozoa, Ciliophora) commonly used by hydrobiologists as bioindicators in rivers, lakes, and waste waters, with notes on their ecology. Freshw Biol 35:375-482

Foissner W, Berger H, Schaumburg J (1999) Identification and ecology of limnetic plankton ciliates. Bayerisches Landesamt für Wasserwirtschaft, Munich

> Glissmann K, Chin KJ, Casper P, Conrad R (2004) Methanogenic pathway and archaeal community structure in the sediment of eutrophic Lake Dagow: effect of temperature. Microb Ecol 48:389-399

Gobler CJ, Davis TW, Deonarine SN, Saxton MA, Lavrentyev PJ, Jochem FJ, Wilhelm SW (2008) Grazing and virus-induced mortality of microbial populations before and during the onset of annual hypoxia in Lake Erie. Aquat Microb Ecol 51:117-128

Guhl BE, Finlay BJ, Schink B (1994) Seasonal development of hypolimnetic ciliate communities in a eutrophic pond. FEMS Microbiol Ecol 14:293-306

Guhl BE, Finlay BJ, Schink B (1996) Comparison of ciliate communities in the anoxic hypolimnia of three lakes: general features and the influence of lake characteristics. J Plankton Res 18:335-353

Hamels I, Muylaert K, Sabbe K, Vyverman W (2005) Contrasting dynamics of ciliate communities in sandy and silty sediments of an estuarine intertidal flat. Eur J Protistol 41:241-250

> Horppila J, Nyberg K, Peltonen H, Turunen T (1996) Effects of five years of intensive trawling on a previously unexploited smelt stock. J Fish Biol 49:329-340

> Jonsson PR (1989) Vertical distribution of planktonic ciliates - an experimental analysis of swimming behaviour. Mar Ecol Prog Ser 52:39-53

Jürgens K, Wickham SA, Rothhaupt KO, Santer B (1996) Feeding rates of macro- and microzooplankton on heterotrophic nanoflagellates. Limnol Oceanogr 41:1833-1839

Kairesalo T, Vakkilainen K (2004) Lake Vesijärvi and the City of Lahti (southern Finland): comprehensive interactions between the lake and the coupled human community. SILnews 41:1-5

- Kankaala P, Huotari J, Peltomaa E, Saloranta T, Ojala A (2006) Methanotrophic activity in relation to methane efflux and total heterotrophic bacterial production in a stratified, humic, boreal lake. Limnol Oceanogr 51: 1195-1204

> Kansanen PH, Jaakkola T, Kulmala S, Suutarinen R (1991) Sedimentation and distribution of gamma emitting radionuclides in bottom sediments of southern Lake Päijänne, Finland, after the Chernobyl accident. Hydrobiologia 222:121-140

Krebs CJ (1999) Ecological methodology. Addison Wesley Longman, Menlo Park, CA

López Bellido J, Peltomaa E, Ojala A (2011) An urban boreal lake basin as a source of $\mathrm{CO}_{2}$ and $\mathrm{CH}_{4}$. Environ Pollut 159:1649-1659

Lynn DH (2008) The ciliated protozoa: characterization, classification, and guide to the literature, 3rd edn. Springer, Dordrecht 
Malinsky-Rushansky NZ, Legrand C (1996) Excretion of dissolved organic carbon by phytoplankton of different sizes and subsequent bacterial uptake. Mar Ecol Prog Ser 132:249-255

Marcus NH (2001) Zooplankton: responses to and consequences of hypoxia. In: Rabalais NN, Turner RE (eds) Coastal hypoxia: consequences for living resources ecosystems. American Geophysical Union, Washington, DC, p 49-60

Mindl B, Sonntag B, Pernthaler J, Vrba J, Psenner R, Posch $\mathrm{T}$ (2005) Effects of phosphorus loading on interactions of algae and bacteria: reinvestigation of the 'phytoplankton-bacteria paradox' in a continuous cultivation system. Aquat Microb Ecol 38:203-213

Müller H, Schöne A, Pinto-Coelho RM, Schweizer A, Weisse $\mathrm{T}$ (1991) Seasonal succession of ciliates in Lake Constance. Microb Ecol 21:119-138

Pace ML (1982) Planktonic ciliates: their distribution, abundance, and relationship to microbial resources in a monomictic lake. Can J Fish Aquat Sci 39:1106-1116

Park JS, Cho BC (2002) Active heterotrophic nanoflagellates in the hypoxic watercolumn of the eutrophic Masan Bay, Korea. Mar Ecol Prog Ser 230:35-45

Peltomaa E, Ojala A (2010) Size-related photosynthesis of algae in a strongly stratified humic lake. J Plankton Res 32:341-355

> Pomeroy LR (2001) Caught in the food web: Complexity made simple? Sci Mar 65(Suppl 2):31-40

Psenner R, Sommaruga R (1992) Are rapid changes in bacterial biomass caused by shifts from top-down to bottomup control? Limnol Oceanogr 37:1092-1100

Rabalais NN, Turner RE, Sen Gupta BK, Boesch D, Chapman P, Murrell MC (2007) Hypoxia in the northern Gulf of Mexico: Does the science support the plan to reduce, mitigate, and control hypoxia? Estuar Coast 30:753-772

Raghukumar S, Schaumann K (1993) An epifluorescence microscope method for direct detection and enumeration of the fungilike marine protists: the thraustochytrids. Limnol Oceanogr 38:182-187

Sanders RW, Porter KG, Bennett SJ, DeBiase AE (1989) Seasonal patterns of bacterivory by flagellates, ciliates, rotifers, and cladocerans in a freshwater planktonic community. Limnol Oceanogr 34:673-687

Sherr BF, Sherr EB (2000) Marine microbes: an overview. In: Kirchman D (ed) Microbial ecology of the oceans. WileyLiss, New York, NY

Sherr EB, Sherr BF (2002) Significance of predation by protists in aquatic microbial food webs. Antonie van Leeuwenhoek 81:293-308

Sherr BF, Sherr EB, Pedrós-Alió C (1989) Simultaneous measurement of bacterioplankton production and protozoan

Editorial responsibility: Matthias Seaman,

Oldendorf/Luhe, Germany bacteriovory in estuarine water. Mar Ecol Prog Ser 54: 209-219

Shinzato N, Watanabe I, Meng XY, Sekiguchi Y, Tamaki H, Matsui T, Kamagata Y (2007) Phylogenetic analysis and fluorescence in situ hybridization detection of archaeal and bacterial endosymbionts in the anaerobic ciliate Trimyema compressum. Microb Ecol 54:627-636

Šimek K, Hartman P, Nedoma J, Pernthaler J, Springmann D, Vrba J, Psenner R (1997) Community structure, picoplankton grazing and zooplankton control of heterotrophic nanoflagellates in a eutrophic reservoir during the summer phytoplankton maximum. Aquat Microb Ecol 12:49-63

> Simon M, Azam F (1989) Protein content and protein synthesis rates of planktonic marine bacteria. Mar Ecol Prog Ser 51:201-213

> Søndergaard M (1991) Phototrophic picoplankton in temperate lakes: seasonal abundance and importance along a trophic gradient. Int Rev Gesamten Hydrobiol 76: 505-522

Søndergaard M, Hansen B, Markager S (1995) Dynamics of dissolved organic carbon lability in a eutrophic lake. Limnol Oceanogr 40:46-54

Steemann-Nielsen E (1952) The use of radio-active carbon $\left(\mathrm{C}^{14}\right)$ for measuring organic production in the sea. J Cons Int Explor Mer 18:117-140

Taipale S, Kankaala P, Tiirola M, Jones RI (2008) Whole-lake dissolved inorganic ${ }^{13} \mathrm{C}$ additions reveal seasonal shift in zooplankton diet. Ecology 89:463-474

Throndsen J (1978) Preservation and storage. In: Sournia A (ed) Phytoplankton manual. UNESCO, Paris, p 69-74

Tulonen T (1993) Bacterial production in a mesohumic lake estimated from $\left[{ }^{14} \mathrm{C}\right]$ leucine incorporation rate. Microb Ecol 26:201-217

Utermöhl H (1958) On the complementation of quantitative phytoplankton methods. Int Ver Theor Angew Limnol Mitt 9:1-38

Vakkilainen K, Nykänen M, Ryynänen T, Tamminen P and others (2010) Vesijärven vedenlaatu- ja planktontietojen päivitys ja raportointi. Vesijärven seurantatutkimus. University of Helsinki, Lahti

Weisse T (1991) The annual cycle of heterotrophic freshwater nanoflagellates: role of bottom-up versus topdown control. J Plankton Res 13:167-185

> Wintermans JFGM, DeMots A (1965) Spectrophotometric characteristics of chlorophylls $a$ and $b$ and their pheophytins in ethanol. Biochim Biophys Acta 109:448-453

Zingel P, Agasild H, Nõges T, Kisand V (2007) Ciliates are the dominant grazers on pico- and nanoplankton in a shallow, naturally highly eutrophic lake. Microb Ecol 53:134-142

Submitted: September 1, 2010; Accepted: September 23, 2011 Proofs received from author(s): December 11, 2011 